\title{
Efficacy of Ethanolic Extract of Syzygium aromaticum in the Treatment of Multidrug-Resistant Pseudomonas aeruginosa Clinical Isolates Associated with Urinary Tract Infections
}

\author{
Osama Ahmed, ${ }^{1}$ Hassan Mohamed $\mathbb{D},{ }^{1,2}$ Wesam Salem $\left(\mathbb{D},{ }^{3}\right.$ Magdy Afifi $\mathbb{D}^{1}$, \\ and Yuanda Song $\mathbb{D}^{2}$ \\ ${ }^{1}$ Department of Botany and Microbiology, Faculty of Science, Al-Azhar University, Assiut 71524, Egypt \\ ${ }^{2}$ Colin Ratledge Center for Microbial Lipids, School of Agricultural Engineering and Food Science, \\ Shandong University of Technology, Zibo 255000, China \\ ${ }^{3}$ Department of Botany and Microbiology, Faculty of Science, South Valley University, Qena 83523, Egypt
}

Correspondence should be addressed to Magdy Afifi; magdybadran.136@azhar.edu.eg and Yuanda Song; ysong@sdut.edu.cn

Received 8 November 2020; Accepted 31 May 2021; Published 16 June 2021

Academic Editor: Xing Li

Copyright (c) 2021 Osama Ahmed et al. This is an open access article distributed under the Creative Commons Attribution License, which permits unrestricted use, distribution, and reproduction in any medium, provided the original work is properly cited.

Pseudomonas aeruginosa is an organism commonly found in the environment and one of the most common causes of human urinary tract infections in developed and developing countries. The present study aimed to investigate the effect of five medicinal plant extracts on the isolated drug-resistant P. aeruginosa clinical isolates. A total of 100 urine samples were collected from Nagaa Hammadi and Qena General Hospitals and private medical analysis laboratories in Qena governorate, Upper Egypt. Samples were screened for the prevalence of UTI pathogens by biochemical tests, antibiotics sensitivity, detection of virulence, and antibioticresistant genes by using multiplex PCR. P. aeruginosa is by far the subdominant causative agent with a percentage of $14 \%$. Clinical isolates were multidrug-resistant, containing $b l a_{\mathrm{TEM}}, b l a_{\mathrm{SHV}}$, tox $A, l a s B, p s l A$, and $f l i C$ resistant and virulence genes. Based on bioactivity, the ethanolic extract of clove (Syzygium aromaticum) was the most active extract among tested medicinal plants and had the maximum zone of inhibition sized $23 \mathrm{~mm}$ against tested bacteria. The results of the minimum inhibitory concentration (MIC) and the minimum bactericidal concentration (MBC) showed a high decrease of inhibition within a concentration range of (10 to $121.25 \mathrm{mg} / \mathrm{mL}$ and 20 to $30 \mathrm{mg} / \mathrm{mL}$, respectively). Further, major compounds of oleic acid (27.22\%), guanosine (8.91\%), indole $(6.83 \%)$, 1-eicosene $(6.30 \%)$, and cis-10-nonadecenoic acid (5.37\%) were determined among 12 bioactive compounds in the ethanolic extract of $S$. aromaticum using gas chromatography-mass spectrometry (GC-MS). These results indicated that the ethanolic extract of $S$. aromaticum is a promising antibacterial agent for further studies aiming to control bacterial infections including MDR bacteria and develop novel therapeutic alternatives for the treatment of UTI.

\section{Introduction}

Microbial infections are a common cause of urinary ailments in humans and have become a common cause of nosocomial disorders. A urinary tract infection (UTI) in humans is one of the most predominant illnesses in developing countries representing more than $35 \%$ of hospitalized patients [1]. It is common in sexually active females and increases in people with diabetes and patients with sickle cell disease or anatomical malformation of the urinary tract; other factors for UTI are an enlarged prostate gland in men and pregnancy in women raising the risk of infection; also, patients with indwelling bladder catheter are predisposed to bacteriuria and UTIs [2]. The family Enterobacteriaceae is the most frequent pathogen detected, causing most of the UTIs, such as Escherichia coli (reaching 77\%), followed by Enterococcus faecalis, Pseudomonas aeruginosa, Klebsiella pneumoniae, Acinetobacter spp., Proteus spp., and Staphylococcus aureus $[3,4]$.

Each organism has its encoding virulence gene(s) that is responsible for the pathogenicity of an infective agent [5]. $P$. aeruginosa is well known as an opportunistic bacterial pathogen [6], essentially dangerous to patients suffering 
from cystic fibrosis and people with a weak immune system [7]. P. aeruginosa infection is often difficult to eradicate because of resistance to multiple antibiotics and disinfectants; it can organize itself in a "biofilm" where it can be protected from antibiotics and immune cells, which ranks as the third most common organism after E. coli and Enterococci associated with urinary tract infections [8]. $P$. aeruginosa clinical isolates are extremely high resistant to multiple antibacterial agents [9] and subsequently have joined the ranks of 'superbugs' because of its broad capacity to create resistance [10].

Multidrug-resistant (MDR) Gram-negative bacteria, currently endemic in many countries, may cause severe infections that are usually associated with high death rates. MDR is the main concern in developing a definitive therapy and treatments for $P$. aeruginosa infections $[11,12]$. Multiple mechanisms of resistance against antibacterial agents have been reported, which include inactivation of drugs by several factors such as enzymatic modification and their actions, target mutation, reduced transport, and/or increased efflux and decreased uptake of the antibiotics [13]. Due to the frequent development of resistance during single-drug therapy treatment of patients associated with $P$. aeruginosa, the natural plant extracts have been reported as an emergent strategy to combat and overcome associated infections and their resistance mechanisms $[14,15]$.

To improve safer medical drugs, several studies on the antimicrobial activity of plant and herbal extracts have been investigated against drug-resistant organisms. Natural bioactive compounds from medicinal plants are among the alternative sources investigated to replace traditional antibiotics and synthetic antimicrobial agents $[14,16]$. The World Health Organization (WHO) estimates that more than $80 \%$ of the people worldwide, mainly in developing countries, use multiple plant extracts and their active molecules as folk medicine in conventional drugs [17]. Several studies have been confirmed as significant antibacterial, antifungal, antiviral, and anticarcinogenic activities of some aromatic herbs such as cinnamon (Cinnamomum zeylanicum), oregano (Origanum vulgare), clove (Syzygium aromaticum), thyme (Thymus vulgaris), and turmeric (Curcuma longa). However, clove has received much attention among other plant spices because it has a great antimicrobial effect against multidrug-resistant and antioxidant activities [18]. In this context, the global emergence of multidrug-resistant bacteria invokes an urgent and imperative necessity for exploring novel antimicrobials against microbial pathogens [19]. Thus, searching for new antibacterial agents, especially from medicinal plants, with narrow-spectrum antibiotics and an actual effective response against resistant pathogenic strains, is an extremely urgent task.

In the present study, we aimed to investigate the antibacterial potential of different medicinal plant extracts against MDR $P$. aeruginosa clinical isolates and their relationship with antimicrobial susceptibility and to determine the resistant patterns of UTI pathogens by multiplex PCR. The chemical constituents of the active plant extract were determined using gas chromatography-mass spectrometry (GC-MS).

\section{Materials and Methods}

2.1. Sampling, Data Collection, and Processing. A total of 100 urine samples were collected from the Nagaa Hammadi and Qena General Hospitals and some private medical analysis laboratories in Qena governorate, Upper Egypt, from January 2018 to January 2019. Samples were collected from patients between the ages of 6 and 81 years asymptomatic with high body temperature and chills, inflammation in the urethra, nausea and vomiting, diarrhoea, mucus, and an open wound treated in the hospital, treatments requiring invasive devices like urinary catheters. Clean catch midstream urine specimens were collected into the sterile screw container from each patient who had not received antibiotics within the last 5 days. Each specimen was clearly labelled and transported on dry ice to the microbiology laboratory for further processing. Urine physical condition, guidelines for sample collection, specific gravity, and their $\mathrm{pH}$ were determined [20].

\subsection{Isolation and Identification of UTI Pathogens.} Collected urine samples were streaked onto sterile MacConkey agar medium containing peptone $17 \mathrm{~g} / \mathrm{L}$; polypeptone $3 \mathrm{~g} / \mathrm{L}$; lactose $10 \mathrm{~g} / \mathrm{L}$; bile salts $1.5 \mathrm{~g} / \mathrm{L}$; sodium chloride $5 \mathrm{~g} / \mathrm{L}$; neutral red $3 \mathrm{~g} / \mathrm{L}$; crystal violet $0.001 \mathrm{~g} / \mathrm{L}$; agar $15 \mathrm{~g} / \mathrm{L}$; distilled water $1000 \mathrm{~mL}$ and final $\mathrm{pH} 7.1 \pm 0.2$ and blood agar medium containing peptone $5 \mathrm{~g} / \mathrm{L}$; beef extract $3 \mathrm{~g} / \mathrm{L}$; sodium chloride $5 \mathrm{~g} / \mathrm{L}$; sheep blood $50 \mathrm{~mL}$; agar $15 \mathrm{~g} / \mathrm{L}$; distilled water $1000 \mathrm{~mL}$ and final $\mathrm{pH} 7.4 \pm 0.2$. Then, plates were incubated at $37^{\circ} \mathrm{C}$ for $24 \mathrm{~h}$. The obtained pure colonies were subcultured onto nutrient agar (NA) media containing peptone $5 \mathrm{~g} / \mathrm{L}$; beef extract $3 \mathrm{~g} / \mathrm{L}$; sodium chloride $5 \mathrm{~g} / \mathrm{L}$; agar $15 \mathrm{~g} / \mathrm{L}$; distilled water $1000 \mathrm{~mL}$ and final $\mathrm{pH} 6.8 \pm 0.2$ and identified by standard biochemical methods [21].

2.3. Antimicrobial Sensitivity Testing. The antibiotic susceptibility testing was performed by the Kirby-Bauer disk diffusion method [22]. Bacterial suspensions used were equal to $0.5 \mathrm{McF}$ arland turbidity $\left(1.5 \times 10^{8} \mathrm{CFU} / \mathrm{mL}\right)$. The tryptic soy agar (TSA) (containing pancreatic digest of casein $15 \mathrm{~g} / \mathrm{L}$; peptic digest of soybean meal $5 \mathrm{~g} / \mathrm{L}$; sodium chloride $5 \mathrm{~g} / \mathrm{L}$; agar $15 \mathrm{~g} / \mathrm{L}$; distilled water $1000 \mathrm{~mL}$ and final $\mathrm{pH} 7.3 \pm 0.2$ ) was seeded with $100 \mu \mathrm{L}$ of the bacterial suspension according to Clinical and Laboratory Standard Institute [23]. The tested antibacterial agents used in this method were as follows: amikacin (AK $30 \mu \mathrm{g}$ ), gentamicin (CN $10 \mu \mathrm{g}$ ), aztreonam (ATM $30 \mu \mathrm{g}$ ), ceftazidime (CAZ $30 \mu \mathrm{g})$, cefoxitin $(30 \mu \mathrm{g})$, ceftriaxone $(30 \mu \mathrm{g})$, cefepime $(30 \mu \mathrm{g})$, ampicillin-sulbactam $(20 / 10 \mu \mathrm{g})$, piperacillintazobactam (PIT 100/10 $\mu \mathrm{g}$ ), imipenem (IPM $10 \mu \mathrm{g}$ ), ciprofloxacin (CIP $5 \mu \mathrm{g}$ ), cefepime (CPM $10 \mu \mathrm{g}$ ), gatifloxacin (GAT $30 \mu \mathrm{g}$ ), norfloxacin (NOR $20 \mu \mathrm{g}$ ), ofloxacin (OF $30 \mu \mathrm{g})$, and tobramycin (TOB $10 \mu \mathrm{g}$ ). Interpretation of the results was performed according to Clinical and Laboratory Standards Institute guidelines to determine if the isolate is resistant or susceptible to the tested antibiotics. 
2.4. Detection of Virulence and Antibiotic-Resistant Genes of Isolated $P$. aeruginosa. Molecular characterization of the recovered urinary tract infection $P$. aeruginosa was carried out by multiplex polymerase chain reaction (PCR). The detected enterotoxins genes for $P$. aeruginosa were $b a_{\text {TEM }}$, $b l a_{\mathrm{SHV}}, b l a_{\mathrm{CTX}}, t o x A$, las $B, p s l A$, and $f l i C$; besides, the $16 \mathrm{~S}$ rDNA gene was performed. The encoding enterotoxins and antibiotic-resistant genes were performed using forward and reverse primers sets. All primer sequences with corresponding references are listed in Table 1.

\subsection{DNA Amplification for the Selected Virulence and Antibiotic} Resistance Genes of Isolates. DNA extraction was carried out according to QIAamp DNA Mini Kit instructions (QIAGEN, Germany, GmbH) as described previously [30] with some modifications. In brief, approximately $200 \mu \mathrm{L}$ of the sample suspension was inoculated with $10 \mu \mathrm{L}$ of proteinase $\mathrm{K}$ and then with $200 \mu \mathrm{L}$ of lysis buffer and incubated for $10 \mathrm{~min}$ at $56^{\circ} \mathrm{C}$. After the incubation period, $200 \mu \mathrm{L}$ of ethanol (96\%) was added to the lysate. The sample was then washed and centrifuged following the manufacturer's instructions. The obtained DNA was eluted with $100 \mu \mathrm{L}$ of elution buffer provided in the kit. PCR amplification was performed using oligonucleotide primers (Metabion, Germany) that were utilized in a $25 \mu \mathrm{L}$ reaction containing $12.5 \mu \mathrm{L}$ of EmeraldAmp GT PCR Master Mix 2x premix (Takara, Japan), $1 \mu \mathrm{L}$ of each primer, $6 \mu \mathrm{L}$ PCR grade $\mathrm{H}_{2} \mathrm{O}$, and $6 \mu \mathrm{L}$ of DNA template. The Applied Biosystems 2720 Thermal Cycler was used for PCR. Studied primers, amplicon sizes, and cycling conditions are summarized in Table 1. The PCR products after amplification were separated by $1 \%$ agarose gel electrophoresis when $20 \mu \mathrm{L}$ of each product was loaded in each gel slot. To determine the DNA fragment sizes, GeneRuler 100 bp ladder (Fermentas, Thermo), Gelpilot $100 \mathrm{bp}$, and Gelpilot $100 \mathrm{bp}$ plus ladders (QIAGEN, USA) were used as a marker for electrophoresis. The gel was visualized via a gel documentation system (Alpha Innotech, Biometra) and the data were analyzed using computer software (Automatic Image Capture, USA).

2.6. Plant Material. Five medicinal plants used in this study were as follows: turmeric (Curcuma longa), clove (Syzygium aromaticum), garlic (Allium sativum), pond seeds (Nigella sativa), and ginger (Zingiber officinale); they were collected from commercial sources in Nagaa Hammadi, Qena, Egypt. Before the extraction, the collected plant materials were washed with sterile water and further dried and then ground to obtain a homogenous powder. The plant species were morphologically photographed for documentation and underwent further assisted taxonomic identification at the Department of Botany and Microbiology, Faculty of Science, South Valley University, Qena, Egypt.

2.7. Preparation of Plant Extracts. Multiple solvents have been employed including water, absolute ethanol, and ethyl acetate to extract the bioactive compounds from medicinal plants. The dried form of each plant was soaked separately with sterile distilled water, ethanol, and ethyl acetate (100 g in $1 \mathrm{~L}$ solvent) for 7 days and extracted by maceration. The obtained extracts were filtered through Buchner funnel with Whatman No.1 filter paper and evaporated by a rotary evaporator (BÜCHI R-114, Switzerland) under reduced pressure to dryness at $45^{\circ} \mathrm{C}$. The plant crude extracts were stored at $4^{\circ} \mathrm{C}$ until use. All extracts were redissolved in dimethyl sulfoxide (DMSO) except the aqueous extract, which redissolved in sterile distilled water at a concentration of $200 \mathrm{mg} / \mathrm{mL}$. Before using bioassay, the reconstituted extract solutions were sterilized by micron syringe filters $(0.45 \mu \mathrm{m})$.

2.8. Antibacterial Screening for the Effectiveness of Selected Plants. The antibacterial activity of the five plants was determined using the standard disc diffusion method as described previously [31]. In brief, Petri plates were prepared with approximately $20 \mathrm{~mL}$ of sterile Mueller-Hinton agar (MHA, $17.5 \mathrm{~g} / \mathrm{L}$ acid hydrolysate of casein, $2.0 \mathrm{~g} / \mathrm{L}$ beef extract, $1.5 \mathrm{~g} / \mathrm{L}$ starch, and $18.0 \mathrm{~g} / \mathrm{L}$ agar in $1000 \mathrm{~mL} \mathrm{H}_{2} \mathrm{O}$, $\mathrm{pH} 7.3 \pm 0.2$ ). Overnight cultures of $P$. aeruginosa clinical isolates $\left(5 \times 10^{4}\right.$ spores $\left./ \mathrm{mL}\right)$ were picked up by sterile swab sticks and streaked on the top of the solid media and allowed to dry completely for $20 \mathrm{~min}$. The plant extract stock concentration $(100 \mathrm{mg} / \mathrm{mL})$ was prepared by dissolving the extract in diluted dimethyl sulfoxide $(10 \%$ DMSO) and sterile-filtered through a $0.2 \mu \mathrm{m}$ pore syringe filter. Sterile Whatman No. 1 filter paper discs of $6 \mathrm{~mm}$ diameter were impregnated with each plant crude extract and discs were stored at $4^{\circ} \mathrm{C}$ before use. Extract-impregnated discs $(20 \mu \mathrm{L})$ were placed on agar plates and incubated for $24 \mathrm{~h}$ at $37^{\circ} \mathrm{C}$. Pure $10 \%$ DMSO $(20 \mu \mathrm{L})$ was used as a negative control, while colistin $(10 \mathrm{mg} / \mathrm{disc})$ was used as a positive control. Then, antibacterial activity was determined by measuring the diameter of inhibition zones in millimeters $(\mathrm{mm})$ against the test bacterial isolates. The experiments were performed in triplicate and the mean values were noted.

\subsubsection{Determination of the Minimum Inhibitory Concentration} (MIC) and Minimum Bactericidal Concentration (MBC). The 2-( $p$-iodophenyl)-3-( $p$-nitrophenyl)-5-phenyl tetrazolium chloride (INT) reduction assay was used to determine the MIC and $\mathrm{MBC}$ as described preciously [32]. Overnight prepared MHB cultures of $P$. aeruginosa clinical isolates were adjusted to $\mathrm{OD}_{600}$ of $0.5 \mathrm{McF}$ arland, and $100 \mu \mathrm{L}$ of each bacterial culture was taken into sterilized 96-well microplate. Then, $20 \mu \mathrm{L}$ of the most active extract was added where ten different concentrations were prepared $\left(10^{-1}\right.$ to $\left.10^{-10}\right)$. The 96 -well microplate was incubated for $24 \mathrm{~h}$ at $37^{\circ} \mathrm{C}$. MIC was determined by the addition of $40 \mu \mathrm{L}$ of (INT) $(0.2 \mathrm{mg} / \mathrm{mL}$, Sigma-Aldrich) to the microplate wells and reincubated for $30 \mathrm{~min}$ at $37^{\circ} \mathrm{C}$; colistin (20\%) was used as a positive control. MIC was defined as the lowest concentration at which colour changes [33]. MBC was determined as previously described [34]. 


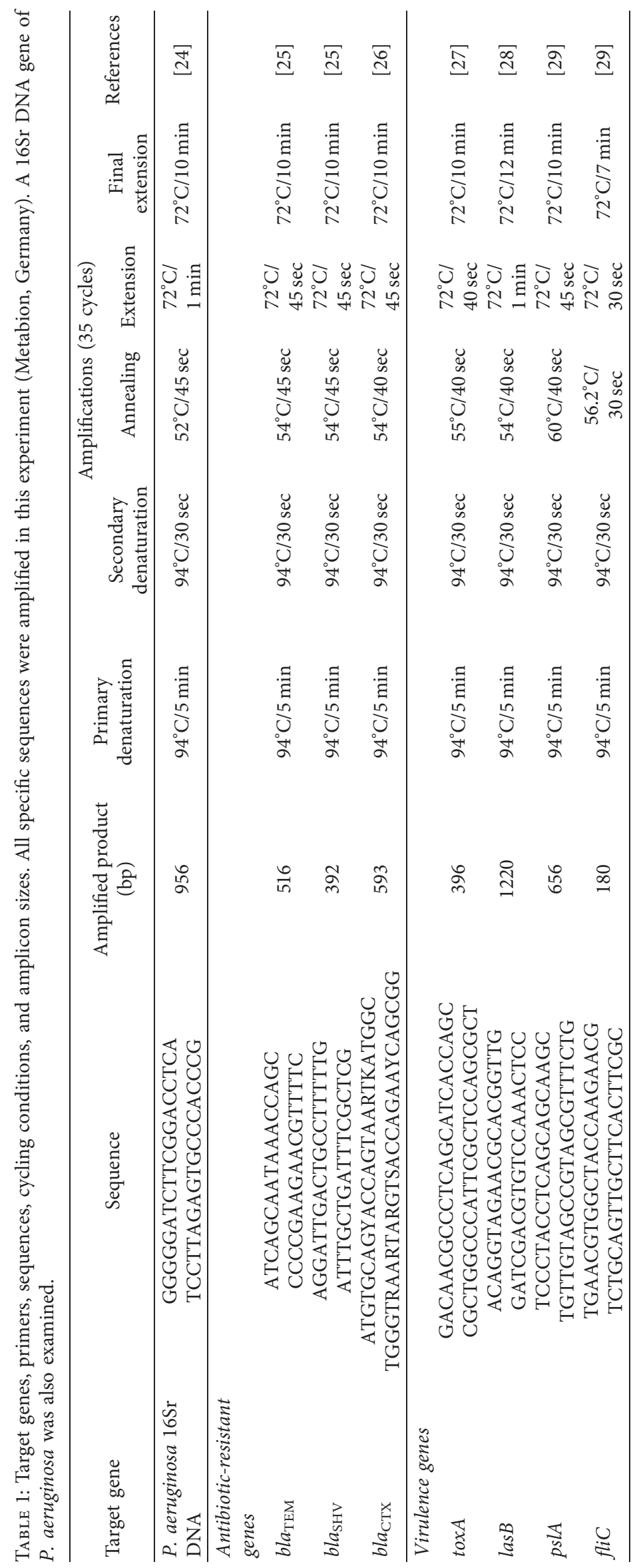


2.9. GC-MS Determination of Bioactive Compounds. The selected active solvent extract was dissolved in methanol (100\%) and dehydrated with anhydrous sodium sulphate and then filtered through a syringe filter $(0.45 \mu \mathrm{m}$ pore size $)$ before injection. A Trace GC1310-ISQ mass spectrometer (Thermo Scientific, Austin, TX, USA) was used for the chromatographic analysis, and the compounds were separated with a direct capillary column TG-5MS $(30 \mathrm{~m} \times 0.25 \mathrm{~mm} \times 0.25 \mu \mathrm{m}$ film thickness). The column temperature was initially $50^{\circ} \mathrm{C}$ and then increased by $5^{\circ} \mathrm{C} /$ min to $230^{\circ} \mathrm{C}$ with holding $2 \mathrm{~min}$ and then increased to $290^{\circ} \mathrm{C}$ at $10^{\circ} \mathrm{C} / \mathrm{min}$. The injector and MS transfer line temperatures were kept at 250 and $260^{\circ} \mathrm{C}$, respectively. Helium was used as a carrier gas at a stable flow rate of $1 \mathrm{~mL} /$ min. The solvent delay was $3 \mathrm{~min}$, and a diluted sample of $1 \mu \mathrm{L}$ was injected automatically using an autosampler AS1300 coupled with GC in the split mode. EI mass spectra were generated at an ionisation voltage of $70 \mathrm{eV}$ with a mass scan of 40-1000 amu. The ion source temperature was set at $200^{\circ} \mathrm{C}$. The extract components were identified by comparison of their retention times and mass spectra with those of WILEY 09 and NIST 11 mass spectral database.

2.10. Statistical Analysis. All the experiments were performed in triplicate. Data were presented as mean \pm SD. GraphPad Prism 6.0 (GraphPad Software, San Diego, CA, USA, https://www.graphpad.com) was used to calculate oneway analysis of the variance (ANOVA) with multiple comparison tests (Tukey's) to evaluate the effect of the different extract.

\section{Results}

3.1. Prevalence of UTI Associated Bacteria. The incidence of the isolated urinary tract infection pathogens in urine sample was recorded from 35\% males and 65\% females patients ( 35 males and 65 females), represented by age under 30 years (10.77 and $14.29 \%)$, from 30 to 60 years $(81.54$ and $68.57 \%$ ), and more than 60 years (7.69 and 17.14\%) for females and males, respectively. All the 100 urine samples that have been properly collected were positive for bacterial growth. The most common predominant organism was E. coli with a percentage of $36 \%$, followed by K. pneumoniae 25\%, P. aeruginosa 14\%, Proteus mirabilis 12\%, Enterobacter cloacae 9\%, and Acinetobacter baumannii 4\% (Figure 1). Total aerobic bacterial count in those samples ranged from 1.9 to $2.10 \times 10^{6} \mathrm{CFU} / \mathrm{mL}$, and $P$. aeruginosa isolates ( $\mathrm{P} 1$ to P14) were preliminary identified by biochemical characterizations and selected for further study (see Table S1 in the Supplementary Materials).

3.2. Antibiotics Sensitivity of P. aeruginosa Clinical Samples. The resistance rate of all isolated UTIs $P$. aeruginosa clinical samples against multiple antibiotics with different influence is shown in Table 2. The results showed that the rate of resistance to all tested antibiotics was $100 \%$ in $P$. aeruginosa isolates (P1, P2, P3, P4, P5, P6, P7, P9, P10, and P11). While the resistance level to all antibiotics was noticed in all

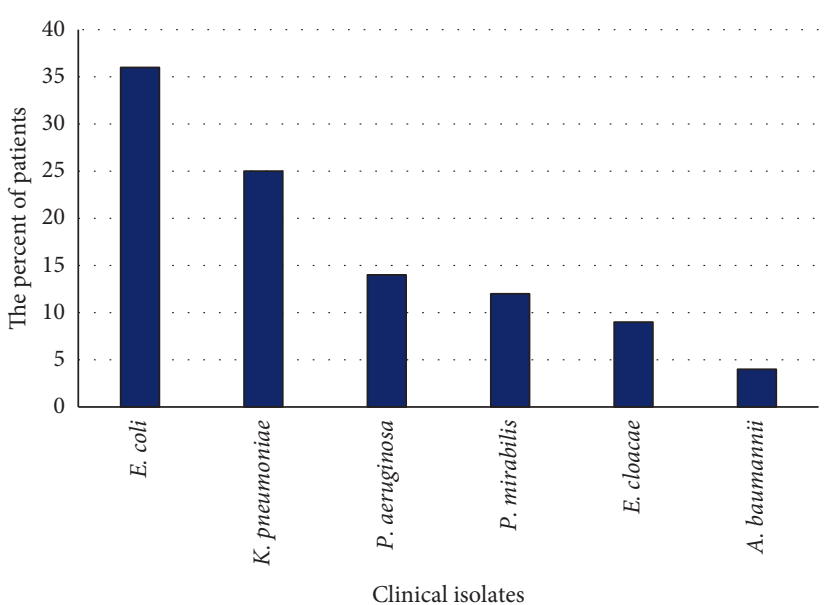

Figure 1: Prevalence of different clinical isolates in urine samples.

isolated samples except $P$. aeruginosa (P4 and P6), they were sensitive for piperacillin-tazobactam. Interestingly, the susceptibility levels of aztreonam, cefepime, ciprofloxacin, norfloxacin, ofloxacin, and piperacillin-tazobactam were observed only against $P$. aeruginosa isolates (P12, P13, and P14), followed by $P$. aeruginosa (P8) that was resistant to $78.5 \%$ of all tested antibiotics. Finally, the sensitivity level of imipenem was detected only against $P$. aeruginosa isolates (P8 and P14).

\subsection{Detection of Antibiotic Resistance and Virulence Genes.} To detect the antibiotic-resistant genes in addition to virulence determinants among $P$. aeruginosa isolates, the multiplex PCR screening was performed. Three different genes $\left(b l a_{\mathrm{TEM}}, b l a_{\mathrm{SHV}}\right.$, and $\left.b l a_{\mathrm{CTX}}\right)$ were applied in this experiment, and the results showed that antibiotic-resistant gene $b l a_{\text {TEM }}$ was present in $6 / 14 P$. aeruginosa isolates (42.8\%). bla $a_{\mathrm{SHV}}$ gene was positive among only two isolates P8 and P9 (16.3\%). Finally, all tested clinical isolates do not contain bla $a_{\mathrm{CTX}}$ antibiotic-resistant gene (Table 2; Figure 2). On the other hand, the multiple virulence genes tox $A$, las $B$, pslA, and $f l i C$ were present in tested $P$. aeruginosa isolates (P4, P8, P9, P12, P13, and P14). However, these virulence genes were not detected in other isolates (Table 2; Figure 3).

3.4. Antibacterial Activity Screening for Selected Plant Extracts. The antibacterial activity of the five plant species was investigated against selected MDR $P$. aeruginosa using the disc diffusion method (Table 3 ). The results revealed that two plant extracts were potentially effective in suppressing $P$. aeruginosa growth with variable potency. The ethyl acetate and ethanolic extracts of C. longa showed varying degrees of antibacterial activities against tested clinical isolates ranging from 7 to $18 \mathrm{~mm}$, while the aqueous, ethanolic, and ethyl acetate extracts of $S$. aromaticum exhibited high percentages of inhibition ranging 7-12, 6-23, and $12-15 \mathrm{~mm}$, respectively, against tested bacteria. On the other hand, the antibacterial activity of $Z$. officinale, $N$. sativa, and A. sativum showed negative effects and all the tested bacteria were resistant to these three plant extracts. Results of 
TABle 2: Antimicrobial sensitivity, antibiotic-resistant genes, and virulence genes of multidrug-resistant $P$. aeruginosa from urine samples.

\begin{tabular}{|c|c|c|c|c|c|c|c|c|c|c|c|c|c|c|}
\hline Clinical isolates & ${ }^{*} \mathrm{P} 1$ & P2 & P3 & $\mathrm{P} 4$ & P5 & P6 & P7 & P8 & P9 & P10 & P11 & P12 & P13 & P14 \\
\hline \multicolumn{15}{|c|}{ Antimicrobial agents $(\mu g)^{* *}$} \\
\hline $\mathrm{AK}$ & $\mathrm{R}$ & $\mathrm{R}$ & $\mathrm{R}$ & $\mathrm{R}$ & $\mathrm{R}$ & $\mathrm{R}$ & $\mathrm{R}$ & $\mathrm{R}$ & $\mathrm{R}$ & $\mathrm{R}$ & $\mathrm{R}$ & $\mathrm{R}$ & $\mathrm{R}$ & $\mathrm{R}$ \\
\hline ATM & $\mathrm{R}$ & $\mathrm{R}$ & $\mathrm{R}$ & $\mathrm{R}$ & $\mathrm{R}$ & $\mathrm{R}$ & $\mathrm{R}$ & $\mathrm{R}$ & $\mathrm{R}$ & $\mathrm{R}$ & $\mathrm{R}$ & $\mathrm{S}$ & $\mathrm{S}$ & S \\
\hline CPM & $\mathrm{R}$ & $\mathrm{R}$ & $\mathrm{R}$ & $\mathrm{R}$ & $\mathrm{R}$ & $\mathrm{R}$ & $\mathrm{R}$ & $\mathrm{R}$ & $\mathrm{R}$ & $\mathrm{R}$ & $\mathrm{R}$ & $\mathrm{S}$ & $\mathrm{S}$ & S \\
\hline CAZ & $\mathrm{R}$ & $\mathrm{R}$ & $\mathrm{R}$ & $\mathrm{R}$ & $\mathrm{R}$ & $\mathrm{R}$ & $\mathrm{R}$ & $\mathrm{R}$ & $\mathrm{R}$ & $\mathrm{R}$ & $\mathrm{R}$ & $\mathrm{R}$ & $\mathrm{R}$ & $\mathrm{R}$ \\
\hline CIP & $\mathrm{R}$ & $\mathrm{R}$ & $\mathrm{R}$ & $\mathrm{R}$ & $\mathrm{R}$ & $\mathrm{R}$ & $\mathrm{R}$ & $\mathrm{R}$ & $\mathrm{R}$ & $\mathrm{R}$ & $\mathrm{R}$ & $\mathrm{S}$ & $\mathrm{S}$ & S \\
\hline GAT & $\mathrm{R}$ & $\mathrm{R}$ & $\mathrm{R}$ & $\mathrm{R}$ & $\mathrm{R}$ & $\mathrm{R}$ & $\mathrm{R}$ & $\mathrm{R}$ & $\mathrm{R}$ & $\mathrm{R}$ & $\mathrm{R}$ & $\mathrm{R}$ & $\mathrm{R}$ & $\mathrm{R}$ \\
\hline $\mathrm{CN}$ & $\mathrm{R}$ & $\mathrm{R}$ & $\mathrm{R}$ & $\mathrm{R}$ & $\mathrm{R}$ & $\mathrm{R}$ & $\mathrm{R}$ & $\mathrm{R}$ & $\mathrm{R}$ & $\mathrm{R}$ & $\mathrm{R}$ & $\mathrm{R}$ & $\mathrm{R}$ & $\mathrm{R}$ \\
\hline IPM & $\mathrm{R}$ & $\mathrm{R}$ & $\mathrm{R}$ & $\mathrm{R}$ & $\mathrm{R}$ & $\mathrm{R}$ & $\mathrm{R}$ & S & $\mathrm{R}$ & $\mathrm{R}$ & $\mathrm{R}$ & $\mathrm{R}$ & $\mathrm{R}$ & S \\
\hline NOR (urine) & $\mathrm{R}$ & $\mathrm{R}$ & $\mathrm{R}$ & $\mathrm{R}$ & $\mathrm{R}$ & $\mathrm{R}$ & $\mathrm{R}$ & S & $\mathrm{R}$ & $\mathrm{R}$ & $\mathrm{R}$ & S & S & S \\
\hline $\mathrm{OF}$ & $\mathrm{R}$ & $\mathrm{R}$ & $\mathrm{R}$ & $\mathrm{R}$ & $\mathrm{R}$ & $\mathrm{R}$ & $\mathrm{R}$ & $\mathrm{R}$ & $\mathrm{R}$ & $\mathrm{R}$ & $\mathrm{R}$ & S & S & S \\
\hline PIT & $\mathrm{R}$ & $\mathrm{R}$ & $\mathrm{R}$ & S & $\mathrm{R}$ & $\mathrm{S}$ & $\mathrm{R}$ & $\mathrm{R}$ & $\mathrm{R}$ & $\mathrm{R}$ & $\mathrm{R}$ & $\mathrm{S}$ & $\mathrm{S}$ & S \\
\hline TOB & $\mathrm{R}$ & $\mathrm{R}$ & $\mathrm{R}$ & $\mathrm{R}$ & $\mathrm{R}$ & $\mathrm{R}$ & $\mathrm{R}$ & $\mathrm{S}$ & $\mathrm{R}$ & $\mathrm{R}$ & $\mathrm{R}$ & $\mathrm{R}$ & $\mathrm{R}$ & $\mathrm{R}$ \\
\hline \multicolumn{15}{|c|}{ Antibiotic-resistant genes ${ }^{* * *}$} \\
\hline$b l a_{\mathrm{TEM}}$ & ND & ND & ND & + & ND & ND & ND & + & + & ND & ND & + & + & + \\
\hline bla $_{\mathrm{SHV}}$ & ND & ND & ND & - & ND & ND & ND & + & + & ND & ND & - & - & - \\
\hline$b l a_{\mathrm{CTX}}$ & ND & ND & ND & - & ND & ND & ND & - & - & ND & ND & - & - & - \\
\hline \multicolumn{15}{|c|}{ Virulence genes**** } \\
\hline toxA & ND & ND & $\mathrm{ND}$ & + & ND & ND & ND & + & + & + & ND & + & + & + \\
\hline las $B$ & ND & ND & ND & + & ND & ND & ND & + & + & + & ND & + & + & + \\
\hline pslA & ND & ND & ND & + & ND & ND & ND & + & + & + & ND & + & + & + \\
\hline fliC & ND & ND & ND & + & ND & ND & ND & + & + & + & ND & + & + & + \\
\hline
\end{tabular}

${ }^{*} 14$ P. aeruginosa different strains (P1-P14). ${ }^{* *}$ Antibiotics: AK: amikacin; ATM: aztreonam; CPM: cefepime; CAZ: ceftazidime; CIP: ciprofloxacin; GAT: gatifloxacin; CN: gentamicin; IPM: imipenem; NOR: norfloxacin; OF: ofloxacin; PIT: piperacillin-tazobactam; TOB: tobramycin. $\mathrm{R}=$ resistant; $\mathrm{S}=$ sensitive.

${ }^{* * *}$ Antibiotic-resistant genes, ${ }^{* * * *}$ virulence genes; +: present; -: absent; ND, not determined.

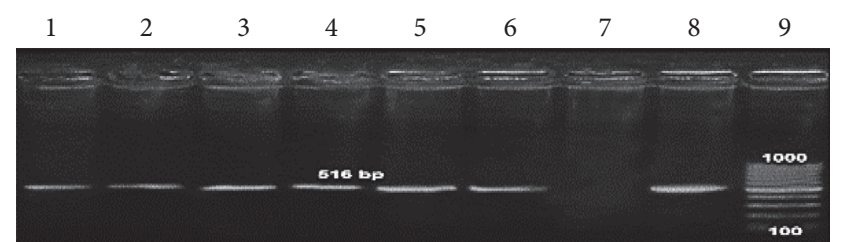

(a)

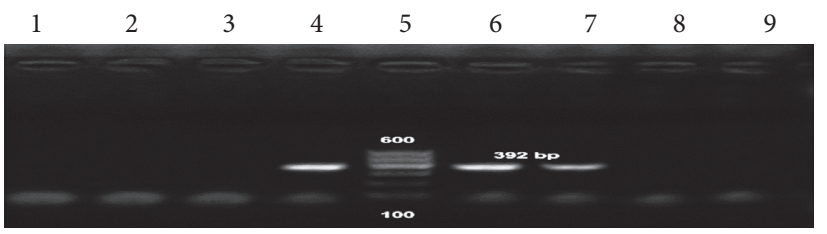

(b)

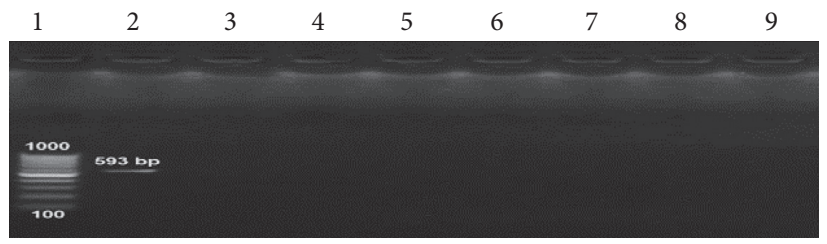

(c)

FIGURE 2: Agarose gel electrophoresis of multiplex PCR of positive P. aeruginosa isolates (6 isolates) carrying antibiotic-resistant genes. (a) bla ${ }_{\mathrm{TEM}}$ antibiotic-resistant gene; lanes 1-6: P. aeruginosa isolates P14, P13, P12, P9, P8, and P4 at 516 bp, lane 7: negative control for detected genes; lane 8: positive control of DNA confirmed by reference laboratory for quality control; lane 9: 100 bp ladder as molecular size

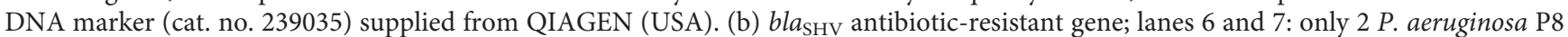
and P9 were $b l a_{\text {SHV }}$ positive; lane 4: positive control of DNA confirmed by reference laboratory for quality control; lane 5: 100 bp ladder as molecular size DNA marker (cat. no. 239035) supplied from QIAGEN (USA). Other lanes were negative $b l a_{\mathrm{SHV}}$ results. (c) $b l a_{\mathrm{CTX}}$ antibioticresistant gene; all $P$. aeruginosa isolates were bla $a_{\mathrm{CTX}}$ negative; lane 1: 100 bp ladder as molecular size DNA marker (cat. no. 239035) supplied from QIAGEN (USA) lane 2: positive control of DNA.

antimicrobial activity of the five plant extracts suggested that the ethanolic extract of $S$. aromaticum was the most effective among other extracts and showed strong antibacterial activity against selected MDR strains. Hence, experiments were conducted to determine their minimal inhibitory concentration (MIC) and minimal bactericidal concentration (MBC) against $P$. aeruginosa bacterial strains.
Moreover, chemical analysis of $S$. aromaticum active extract was performed.

3.5. Minimum Inhibitory and Bacteriostatic Concentration. The MIC and MBC were the lowest and bactericidal concentrations that inhibited bacterial growth, respectively, and 


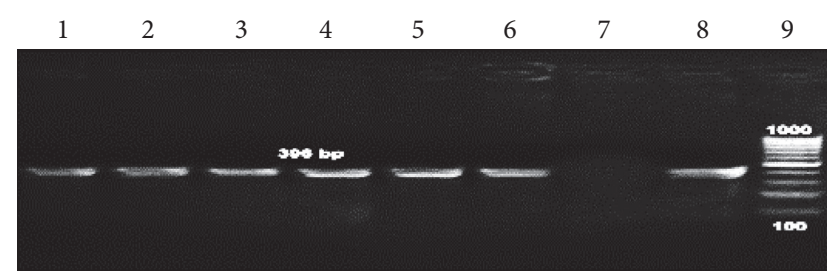

(a)

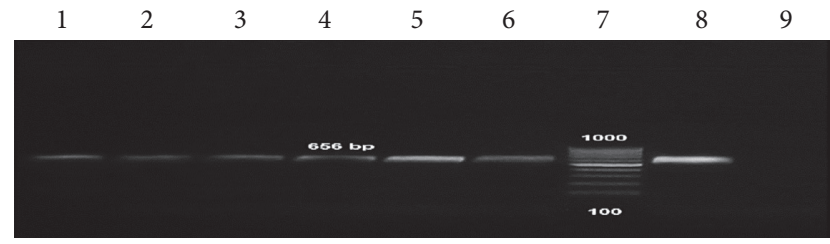

(c)

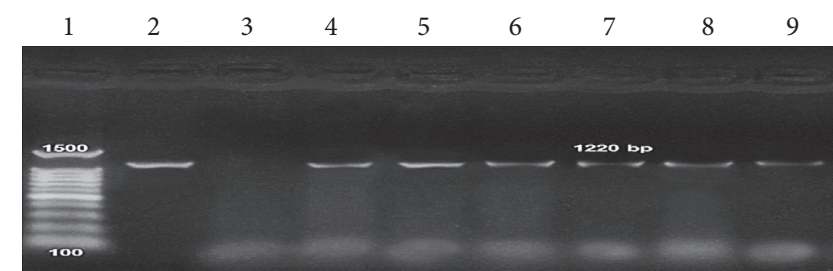

(b)

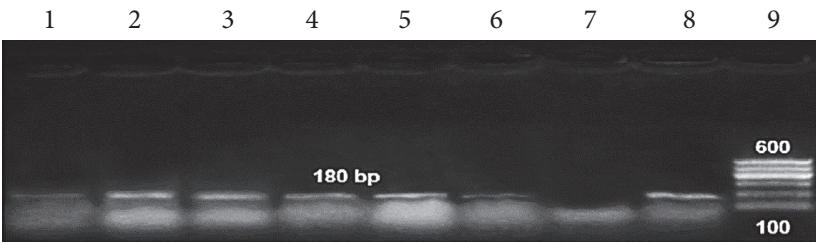

(d)

FIgURE 3: Agarose gel electrophoresis of multiplex PCR of virulence genes characterized for $P$. aeruginosa isolates (6 isolates). Virulenceassociated genes were detected in all $P$. aeruginosa isolates at 396, 1220, 656, and $180 \mathrm{bp}$ in toxA, lasB, pslA, and fliC, respectively. (a) toxA and (d) fliC virulence genes; lane 7: negative control for detected genes; lane 8: positive control of DNA confirmed by reference laboratory for quality control; lane 9: gel pilot $100 \mathrm{bp}$ ladder as molecular size DNA marker (cat. no. 239045) supplied from QIAGEN (USA). (b) lasB virulence gene; lane 3: negative control for detected genes; lane 2: positive control of DNA confirmed by reference laboratory for quality control; lane 1: gel pilot 100 bp ladder as molecular size DNA marker (cat. no. 239045) supplied from QIAGEN (USA). (c) pslA virulence gene; lane 9: negative control for detected genes; lane 8: positive control of DNA confirmed by reference laboratory for quality control; lane 7: gel pilot $100 \mathrm{bp} \mathrm{ladder} \mathrm{as} \mathrm{molecular} \mathrm{size} \mathrm{DNA} \mathrm{marker} \mathrm{(cat.} \mathrm{no.} \mathrm{239045)} \mathrm{supplied} \mathrm{from} \mathrm{QIAGEN} \mathrm{(USA).}$

were determined using the microdilution method with the help of (INT) reduction assay. MIC values of S. aromaticum ethanolic extract ranged from 10 to $21.25 \mathrm{mg} / \mathrm{mL}$, while the MIC of colistin (positive control) was 1 to $2 \mathrm{mg} / \mathrm{mL}$ against all the tested isolates. The ethanolic extracts from S. aromaticum displayed the minimum MIC activity against bacterial isolate P13 with a MIC value of $10 \mathrm{mg} / \mathrm{mL}$ among tested isolates, while $\mathrm{P} 14$ showed the maximum MIC value at $21.25 \mathrm{mg} / \mathrm{mL}$. As for MBC, the ethanolic extract of $S$. aromaticum showed high bactericidal activity at a concentration of 20 to $30 \mathrm{mg} / \mathrm{mL}$. A bactericidal action was observed at a concentration of $30 \mathrm{mg} / \mathrm{mL}$ in the case of $\mathrm{P} 4$ and P9 isolates, while in the case of other tested isolates, $\mathrm{MBC}$ is $20 \mathrm{mg} / \mathrm{mL}$. MBC of colistin (positive control) ranged from 2 to $4 \mathrm{mg} / \mathrm{mL}$ (Figure 4 ).

3.6. Identification of Bioactive Compounds by GC-MS. The bioactive chemical compounds present in the ethanolic extract obtained from S. aromaticum are analyzed by GC-MS (Table 4). The GC-MS analysis data showed the presence of 12 known bioactive compounds in the plant ethanolic extract, which were likely responsible for the antibacterial activity found in the plant extract against the tested bacteria. The retention time, molecular formula, and peak area of these compounds were also presented. Based on abundance, the highest five major compounds present in the ethanolic extract were oleic acid (27.22\%), guanosine (8.91), indole (6.83\%), 1-eicosene $(6.30 \%)$, and cis-10-nonadecenoic acid (5.37\%), and their detected compounds peak are ranged from 0.36 to $2.54 \%$. The GC chromatogram with their concentration peak area (\%), peak number, and retention time $(\mathrm{RT})$ is presented (Table 4; Figure 5).

\section{Discussion}

During the past few decades, the prevalence of microbial infections has increased significantly. Continuous use of antimicrobial drugs in treating such infections has led to the emergence of resistance among the various microbial strains. MDR is defined as a simultaneous resistance of an organism to the administered antimicrobial drugs that are structurally unrelated and have different molecular targets, despite its sensitivity $[35,36]$. Many different types of MDR bacteria such as methicillin-resistant Staphylococcus aureus (MRSA), vancomycin-resistant Enterococcus (VRE), penicillin-resistant Streptococcus pneumoniae, P. aeruginosa, and $E$. coli have been paid increased attention as their potential bacterial pathogenicity and human infections [37]. Drug resistance of mainly $P$. aeruginosa from different clinical specimens in Egypt is one of the main active pathogens in Egyptians, and these organisms associated with UTIs have been little studied [38].

In the present study, 100 urine samples were collected from asymptomatic UTIs patients in Nagaa Hammadi and Qena General Hospitals and other medical laboratories; all collected samples had UTIs with predominant organisms such as E. coli, K. pneumoniae, $P$. aeruginosa, $P$. mirabilis, E. cloacae, and A. baumannii. Moreover, P. aeruginosa isolated strains were selected for the current study and the emergence of antibiotic resistance of $P$. aeruginosa is a worldwide threat as it affects persons globally. According to our analysis results of the urinary samples, approximately $71.5 \%(n=10 / 14)$ of $P$. aeruginosa isolates were resistant to tested antibiotics. A high rate of antibiotic resistance was also demonstrated in a similar Egyptian research study in which $45 \%$ of $P$. aeruginosa isolates exhibited resistance to ceftazidime antibiotics [39]. Also, other studies showed a 


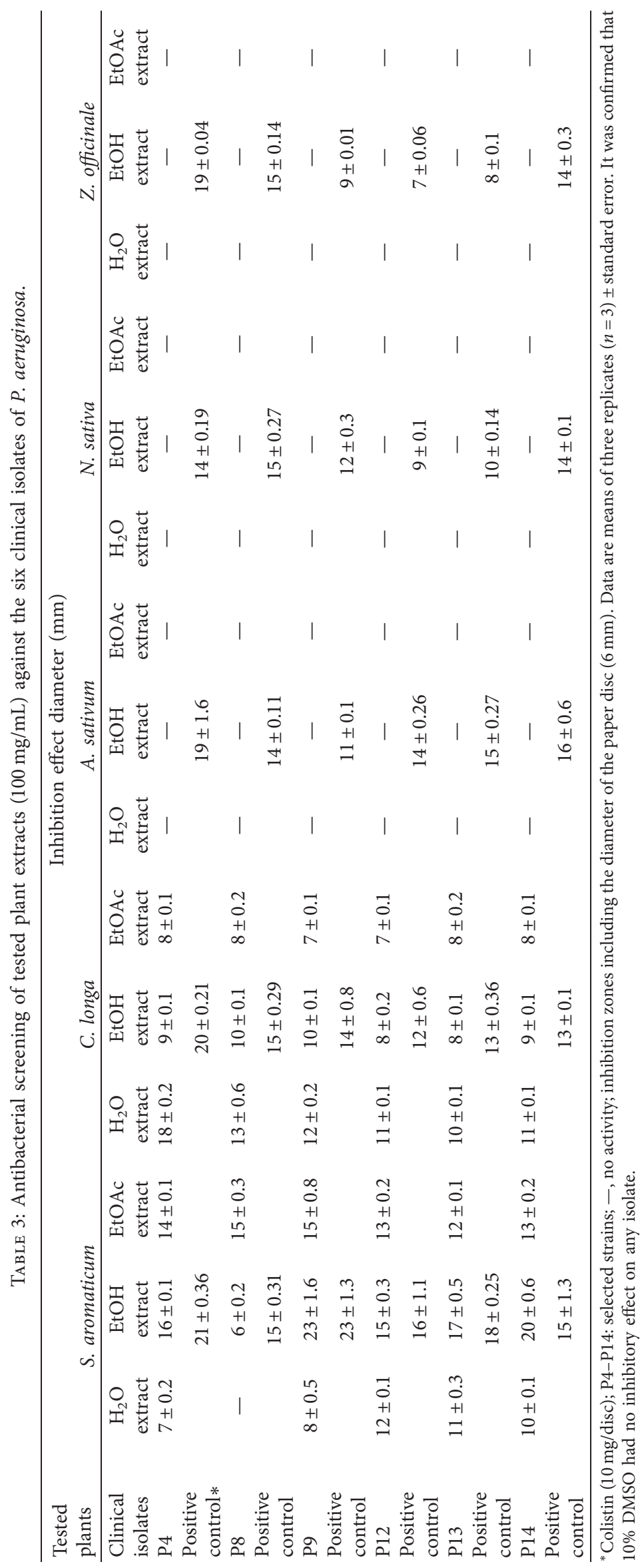




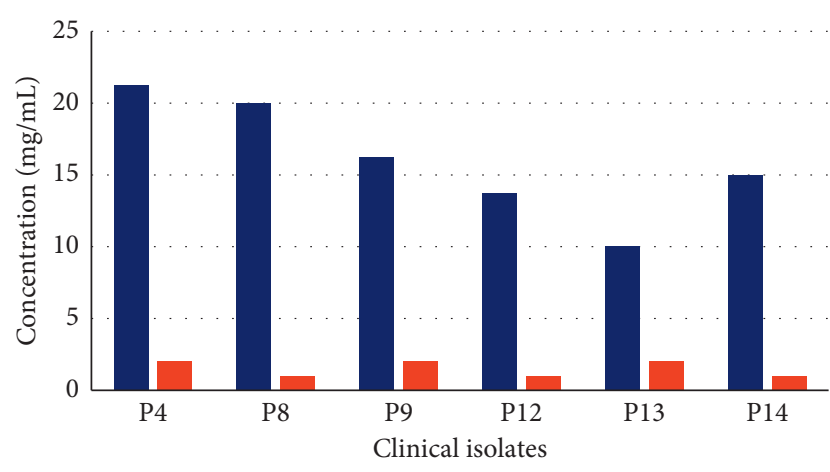

- MIC

— ${ }^{*} \mathrm{MIC}$ control

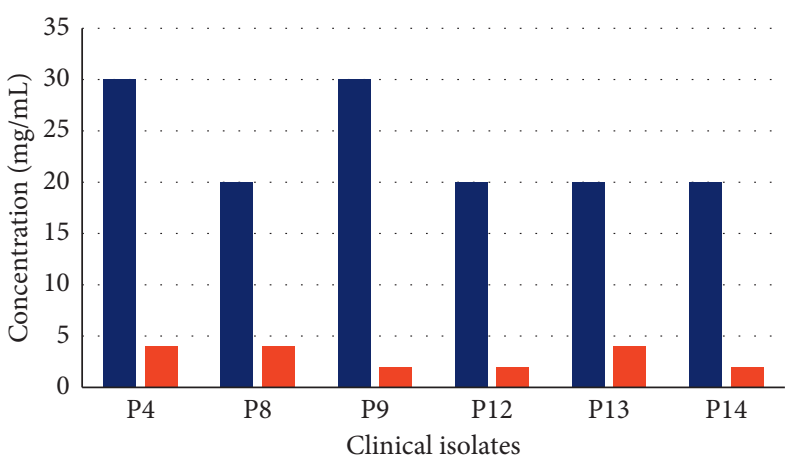

- $\mathrm{MBC}$

- ${ }^{*} \mathrm{MBC}$ control

(a)

(b)

Figure 4: MIC (a) and MBC (b) values of S. aromaticum ethanolic extract $(100 \mathrm{mg} / \mathrm{mL})$ against selected P. aeruginosa. ${ }^{*}$ Colstin as control $(10 \mathrm{mg} / \mathrm{mL})$.

TABLE 4: Bioactive chemical components of the ethanolic extract from S. aromaticum.

\begin{tabular}{|c|c|c|c|c|c|}
\hline No. & Compounds & Chemical formula & Molecular weight & $\mathrm{RT}(\min )$ & Area (\%) \\
\hline 1 & Pentenenitrile & $\mathrm{C}_{5} \mathrm{H}_{7} \mathrm{~N}$ & 81 & 28.33 & 4.37 \\
\hline 2 & Ethyl oleate & $\mathrm{C}_{20} \mathrm{H}_{38} \mathrm{O}_{2}$ & 310 & 29.66 & 2.54 \\
\hline 3 & cis-10-Nonadecenoic acid & $\mathrm{C}_{19} \mathrm{H}_{36} \mathrm{O}_{2}$ & 296 & 32.17 & 5.37 \\
\hline 4 & Indole & $\mathrm{C}_{8} \mathrm{H}_{7} \mathrm{~N}$ & 117 & 35.12 & 6.83 \\
\hline 5 & Guanosine & $\mathrm{C}_{10} \mathrm{H}_{13} \mathrm{~N}_{5} \mathrm{O}_{5}$ & 283 & 37.21 & 8.91 \\
\hline 6 & Oleic acid & $\mathrm{C}_{18} \mathrm{H}_{34} \mathrm{O}_{2}$ & 282 & 39.55 & 27.22 \\
\hline 7 & Chlorozotocin & $\mathrm{C}_{9} \mathrm{H}_{16} \mathrm{ClN}_{3} \mathrm{O}_{7}$ & 313 & 39.75 & 0.52 \\
\hline 8 & 1-Eicosene & $\mathrm{C}_{20} \mathrm{H}_{40}$ & 280 & 40.62 & 6.30 \\
\hline 9 & Nonadecene & $\mathrm{C}_{19} \mathrm{H}_{38}$ & 266 & 46.77 & 1.20 \\
\hline 10 & 3-Hexacosanol & $\mathrm{C}_{26} \mathrm{H}_{54} \mathrm{O}$ & 382 & 48.85 & 2.21 \\
\hline 11 & Nonacosane & $\mathrm{C}_{29} \mathrm{H}_{60}$ & 408 & 51.96 & 0.36 \\
\hline 12 & Dodecanoic acid & $\mathrm{C}_{12} \mathrm{H}_{24} \mathrm{O}_{2}$ & 200 & 53.70 & 2.34 \\
\hline
\end{tabular}

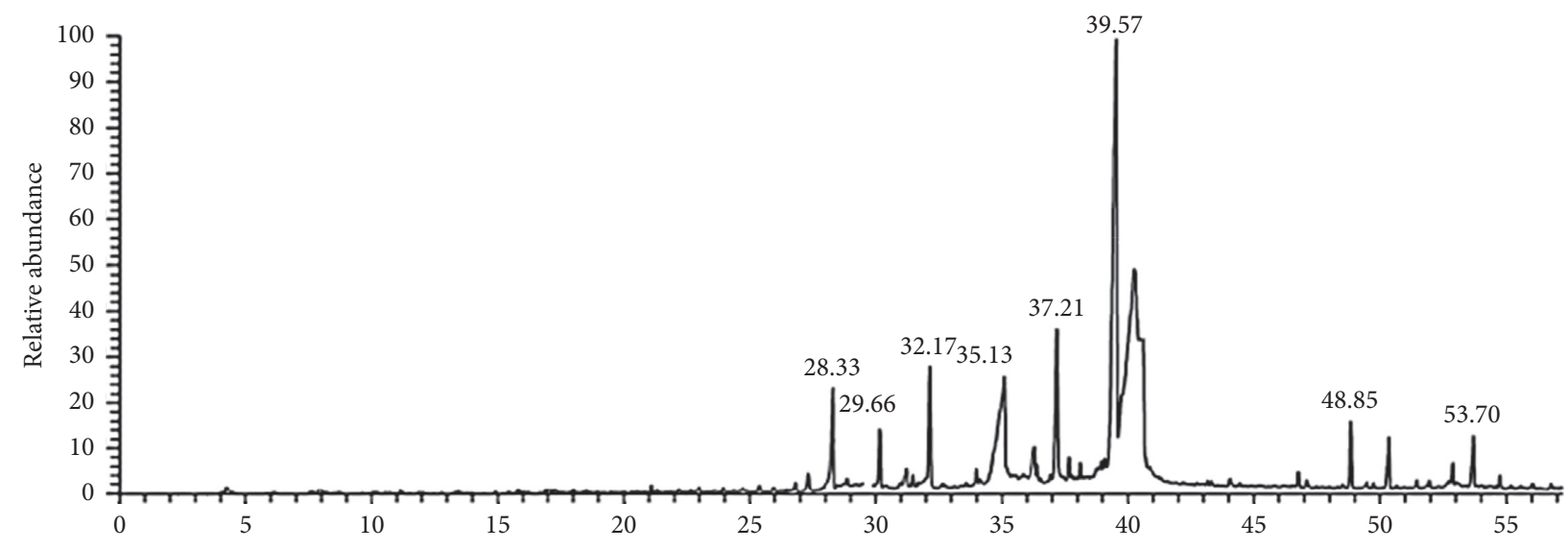

FIGURE 5: A typical chromatogram of the biologically active compounds present in the ethanolic extract of S. aromaticum.

91\% resistance rate in other regions of Egypt [40]. Prior studies by Rodríguez-Martínez [41] showed that approximately $87 \%$ of $P$. aeruginosa isolates were resistant against imipenem, and $100 \%$ resistance against ciprofloxacin was reported by Tam et al. [42], which is in agreement with our findings. Our study was also supported by Meenakumari et al., where amikacin and gentamicin antibiotics were resistant to $P$. aeruginosa clinical isolates [43]. Contrary to our study, $P$. aeruginosa strains showed 20 and $100 \%$ resistance to cotrimoxazole, which were reported in Libya and Nigeria, respectively [44, 45].

Our data showed that $b l a_{\text {TEM }}$ antibiotic-resistant gene was present in $P$. aeruginosa isolates $(42.8 \%)$, while bla $a_{\mathrm{SHV}}$ 
was positive only in two isolates (16.3\%). Interestingly, all tested isolates do not contain $b{ } a_{\mathrm{CTX}}$ antibiotic-resistant gene. On the other hand, the virulence genes toxA, las $B$, pslA, and $f l i C$ were detected in $P$. aeruginosa isolates (42.8\%). A study in 2018 by Al Dawodeyah et al. [46] reported that the positive results for $b l a_{\mathrm{CTX}-\mathrm{M}}, b l a_{\mathrm{TEM}}, b l a_{\mathrm{VEB}}, b l a_{\mathrm{SHV}}$, and $b l a_{\mathrm{GES}}$ genes were detected in $P$. aeruginosa clinical isolates with the percentage of $68.9,18.9,18.9,12.5$, and $15.6 \%$, respectively. They found no specific relation between the resistance to antibiotics, the existence of virulence genes, and their genotypes between MDR $P$. aeruginosa isolates.

Bioactive products from medicinal plants have been studied for decades, which is one of the most successful sources of drugs to treat bacterial infections. Accordingly, there is urgent demand for the discovery of novel antibiotics with new modes of action against multidrug-resistant bacteria. Antimicrobial constituents of natural origin have the potential to play a great therapeutic role in treating infectious diseases [47]. Antibacterial activity of five plants and their sequential extracts (aqueous, ethanol, and ethyl acetate) were subjected to bioactivity screening against six MDR $P$. aeruginosa bacterial strains that exhibited resistance to various antibiotics. Our results showed that only ethanolic extracts of S. aromaticum and C. longa were highly effective against $P$. aeruginosa isolates with maximum inhibition zone ranging between 23 and $10 \mathrm{~mm}$, respectively, while other tested plants and their extracts had no activity against tested bacteria (100\% resistant). Similar results reported by Alharbi [48] confirmed that the ethanolic extract of S. aromaticum has bactericidal activity on $P$. aeruginosa ATCC 27853 and bacteriostatic on $P$. aeruginosa clinical isolates. Other research works conducted in parallel investigated the highly effective methanolic extract of $S$. aromaticum against MDR $P$. aeruginosa [49]. In the earlier study [50], they focused on the activity of medicinal plants such as Aloe vera and C. longa, which showed antimicrobial activity against Gramnegative bacteria. Our study can be supported by the work of Aziz et al. [51], who demonstrated that the extracts of S. aromaticum had remarkable antimicrobial activities and showed a convincing zone of inhibition against the tested MDR $P$. aeruginosa strains, and they are relatively more susceptible than the other Gram-negative, especially those isolated from urine samples of UTI patients. These results can be satisfied by the data of previous studies in which the $S$. aromaticum ethanolic extracts showed the maximum inhibition potential towards MDR bacteria [52].

The bioactive constituents responsible for its activity of S. aromaticum have been determined by GC analysis. The GC-MS analysis profile of the plant extract revealed 12 major compounds. Oleic acid, guanosine, indole, 1-eicosene, and cis-10-nonadecenoic acid were the main compounds in the ethanolic extract of $S$. aromaticum. A previous study showed that the oleic acid produced by marine bacteria inhibits pathogenic Gram-negative bacteria and might indicate an influence in the medical treatments [53-55]. Other important active compounds such as hexacosanol, indole, and dodecanoic acid have been reported with a wide range of pharmaceutical activities, such as antibacterial, anticancer, and antitumor activities [53-55].

\section{Conclusions}

The analysis of the activity of biomolecules produced by medicinal plants, particularly $S$. aromaticum, is important due to the decreased efficiency of known antimicrobials, and it is necessary to explore new therapeutic alternatives for the treatment of UTIs. To the best of our knowledge, this study may be the first in Upper Egypt to investigate the potential activity of $S$. aromaticum ethanolic against the multidrugresistant $P$. aeruginosa clinical strains, which carry antibiotic resistance and virulence genes as confirmed by multiplex PCR. However, the isolation of compounds from the S. aromaticum is a great challenge that should be considered to use these individual compounds for biomedical therapeutics against MDR bacteria. This research may serve as a fruitful platform to explore and test the obtained compounds against uropathogens.

\section{Data Availability}

No data were used to support this study.

\section{Disclosure}

The funding bodies had no role in the design of the study or collection, analysis, and interpretation of data or in writing the manuscript.

\section{Conflicts of Interest}

The authors declare that there are no conflicts of interest regarding the publication of this article.

\section{Authors' Contributions}

Osama Ahmed and Hassan Mohamed contributed equally to this work.

\section{Acknowledgments}

This work was supported by Prof. Yuanda Song through the National Natural Science Foundation of China (Grants nos. 31972851 and 31670064) and TaiShan Industrial Experts Programme (no. tscy20160101). The authors would like to extend their appreciation to the Botany and Microbiology Department, Faculty of Science at Al-Azhar University, for providing the lab and instrumental facilities.

\section{Supplementary Materials}

Table S1: biochemical identification of $P$. aeruginosa isolates by Vitek 2 system. (Supplementary Materials)

\section{References}

[1] R. Ganesh, D. Shrestha, B. Bhattachan, and G. Rai, "Epidemiology of urinary tract infection and antimicrobial resistance in a pediatric hospital in Nepal," BMC Infectious Diseases, vol. 19, no. 1, p. 420, 2019.

[2] D. S. Mandell, M. M. Novak, and C. D. Zubritsky, "Factors associated with age of diagnosis among children with autism 
spectrum disorders," Pediatrics, vol. 116, no. 6, pp. 1480-1486, 2005, p.

[3] A. Mansour, M. Manijeh, and P. Zohreh, "Study of bacteria isolated from urinary tract infections and determination of their susceptibility to antibiotics," Jundishapur Journal of Microbiology, vol. 2, no. 3, pp. 118-123, 2009.

[4] M. A. Belete and M. Saravanan, "A systematic review on drug resistant urinary tract infection among pregnant women in developing countries in Africa and Asia; 2005-2016," Infection and Drug Resistance, vol. 13, no. 13, pp. 1465-1477, 2020.

[5] R. B. Elamary, F. M. Albarakaty, and W. M. Salem, "Efficacy of Acacia nilotica aqueous extract in treating biofilm-forming and multidrug resistant uropathogens isolated from patients with UTI syndrome," Scientific Reports, vol. 10, no. 1, Article ID 11125, 2020.

[6] P. D. Lister, D. J. Wolter, and N. D. Hanson, "Antibacterialresistant Pseudomonas aeruginosa: clinical impact and complex regulation of chromosomally encoded resistance mechanisms," Clinical Microbiology Reviews, vol. 22, no. 4, pp. 582-610, 2009.

[7] H. Mulcahy, L. Charron-Mazenod, and S. Lewenza, "Extracellular DNA chelates cations and induces antibiotic resistance in Pseudomonas aeruginosa biofilms," PLoS Pathogens, vol. 4, no. 11, Article ID e1000213, 2008.

[8] S. J. Cole, A. R. Records, M. W. Orr, S. B. Linden, and V. T. Lee, "Catheter-associated urinary tract infection by Pseudomonas aeruginosa is mediated by exopolysaccharideindependent biofilms," Infection and Immunity, vol. 82, no. 5, pp. 2048-2058, 2014.

[9] N. Mesaros, P. Nordmann, P. Plésiat et al., "Pseudomonas aeruginosa: resistance and therapeutic options at the turn of the new millennium," Clinical Microbiology and Infection, vol. 13, no. 6, pp. 560-578, 2007.

[10] E. B. M. Breidenstein, C. de la Fuente-Núñez, and R. E. W. Hancock, "Pseudomonas aeruginosa: all roads lead to resistance," Trends in Microbiology, vol. 19, no. 8, pp. 419-426, 2011.

[11] M. D. Obritsch, D. N. Fish, R. MacLaren, and R. Jung, "National surveillance of antimicrobial resistance in Pseudomonas aeruginosa isolates obtained from intensive care unit patients from 1993 to 2002," Antimicrobial Agents and Chemotherapy, vol. 48, no. 12, pp. 4606-4610, 2004.

[12] D. R. Giacobbe, T. Giani, M. Bassetti, A. Marchese, C. Viscoli, and G. M. Rossolini, "Rapid microbiological tests for bloodstream infections due to multidrug resistant Gramnegative bacteria: therapeutic implications," Clinical Microbiology and Infection, vol. 26, no. 6, pp. 713-722, 2020.

[13] L. Heejeong, C. Hyemin, L. Je Chul, C. Yoo, W. Eun-Rhan, and G. Dong, "Antibacterial activity of hibicuslide C on multidrug-resistant Pseudomonas aeruginosa isolates," Current Microbiology, vol. 73, no. 4, pp. 519-526, 2016.

[14] C. Liu, H. Huang, Q. Zhou et al., "Antibacterial and antibiotic synergistic activities of the extract from Pithecellobium clypearia against clinically important multidrug-resistant gramnegative bacteria," European Journal of Integrative Medicine, vol. 32, Article ID 100999, 2019.

[15] J. Kou, T. Y. Xin, P. McCarron et al., "Going beyond antibiotics: natural plant extracts as an emergent strategy to combat biofilm-associated infections," Journal of Environmental Pathology, Toxicology and Oncology, vol. 39, no. 2, pp. 125-136, 2020.

[16] S. Amer, M. M. Aly, and S. Sabbagh, "Biocontrol of dermatophytes using some plant extracts and actinomycetes filtrates," Egyptian Journal of Biotechnology, vol. 14, pp. 291315, 2007.

[17] S. Kirbag, F. Zengin, and M. Kursat, "Antimicrobial activities of extracts of some plants," Pakistan Journal of Botany, vol. 41, no. 4, pp. 2067-2070, 2009.

[18] G. El-Saber Batiha, L. M. Alkazmi, L. G. Wasef, A. M. Beshbishy, E. H. Nadwa, and E. K. Rashwan, "Syzygium aromaticum L. (Myrtaceae): traditional uses, bioactive chemical constituents, pharmacological and toxicological activities," Biomolecules, vol. 10, no. 2, p. 202, 2020.

[19] H. M. Thomas, B. Stuart, and M. D. Levy, "Confronting the antibiotic resistance crisis: making appropriate therapeutic decisions in community medical practice," Infections in Medicine, vol. 21, no. 3, pp. 114-122, 2004.

[20] B. A. Forbes, D. F. Sahm, A. S. B. Weissfeld, and Scott's, Diagnostic Microbiology, Mosby Elsevier, St. Louis, MO, USA, 12th edition, 2007.

[21] K. Begum, T. Ahmed, M. Haque et al., "Isolation, identification and antibiotic resistance pattern of Salmonella spp. from chicken eggs, intestines and environmental samples," Bangladesh Journal of Pharmacology, vol. 13, no. 1, pp. 23-27, 2010.

[22] A. W. Bauer, W. M. M. Kirby, J. C. Sherris, and M. Turck, "Antibiotic susceptibility testing by a standardized single disk method," American Journal of Clinical Pathology, vol. 45, no. 4, pp. 493-496, 1966

[23] Clinical and Laboratory Standards Institute (CLSI), "Document M100: performance standards for susceptibility testing," Clinical and Laboratory Standards Institute, vol. 37, no. 1, p. 282, 2017.

[24] T. Spilker, T. Coenye, P. Vandamme, and J. J. LiPuma, "PCRbased assay for differentiation of $P$. aeruginosa from other Pseudomonas species recovered from cystic fibrosis patients," Journal of Clinical Microbiology, vol. 42, no. 5, pp. 2074-2079, 2004.

[25] K. Colom, J. Pérez, R. Alonso, A. Fernández-Aranguiz, E. Lariño, and R. Cisterna, "Simple and reliable multiplex PCR assay for detection of $b l a_{\mathrm{TEM}}, b l a_{\mathrm{SHV}}$ and $b l a_{\mathrm{OXA}^{-1}}$ genes in Enterobacteriaceae," FEMS Microbiology Letters, vol. 223, no. 2, pp. 147-151, 2003.

[26] M. Archambault, P. Petrov, R. S. Hendriksen et al., "Molecular characterization and occurrence of extended-spectrum $\beta$-lactamase resistance genes among Salmonella enterica serovar Corvallis from Thailand, Bulgaria, and Denmark," Microbial Drug Resistance, vol. 12, no. 3, pp. 192-198, 2006.

[27] G. M. Matar, F. Ramlawi, N. Hijazi, I. Khneisser, and A. M. Abdelnoor, "Transcription levels of Pseudomonas aeruginosa exotoxin A gene and severity of symptoms in patients with otitis externa," Current Microbiology, vol. 45, no. 5, pp. 350-354, 2002.

[28] S. Finnan, J. P. Morrissey, F. O’Gara, and E. F. Boyd, "Genome diversity of Pseudomonas aeruginosa isolates from cystic fibrosis patients and the hospital environment," Journal of Clinical Microbiology, vol. 42, no. 12, pp. 5783-5792, 2004.

[29] A. Ghadaksaz, A. A. I. Fooladi, H. Mahmoodzadeh Hosseini, and M. Amin, "The prevalence of some Pseudomonas virulence genes related to biofilm formation and alginate production among clinical isolates," Journal of Applied Biomedicine, vol. 13, no. 1, pp. 61-68, 2015.

[30] D. Prakash and R. S. Saxena, "Antimicrobial susceptibility pattern of human pathogenic bacteria related to Enterobacteriaceae family causing urinary tract infection," Advances in Applied Science Research, vol. 4, no. 3, pp. 98-104, 2013. 
[31] T. Y. Mohamed, A. A. Abdulaziz, A. M. Ashraf, and A. E. Mohamed, "Bioactivity of Syzygium aromaticum (L.) Merr. \& L.M. Perry extracts as potential antimicrobial and anticancer agents," Journal of King Saud University-Science, vol. 32, no. 8, pp. 3273-3278, 2020.

[32] W. M. Salem, D. M. W. Shibat El-hamed, W. F. Sayed, and R. B. Elamary, "Alterations in virulence and antibiotic resistant genes of multidrug-resistant Salmonella serovars isolated from poultry: the bactericidal efficacy of Allium sativum," Microbial Pathogenesis, vol. 108, pp. 91-100, 2017.

[33] N. Lall, C. J. Henley-Smith, M. N. De Canha, C. B. Oosthuizen, and D. Berrington, "Viability reagent, PrestoBlue, in comparison with other available reagents, utilized in cytotoxicity and antimicrobial assays," International Journal of Microbiology, vol. 2013, Article ID 420601, 5 pages, 2013.

[34] A. Sirelkhatim, S. Mahmud, A. Seeni et al., "Review on zinc oxide nanoparticles: antibacterial activity and toxicity mechanism," Nano-Micro Letters, vol. 7, no. 3, pp. 219-242, 2015.

[35] V. Singh, "Antimicrobial resistance," in Microbial Pathogens and Strategies for Combating them: Science, Technology and Education, vol. 1, pp. 910-921, Formatex Research Center, Badajoz, Spain, 2013.

[36] M. Popęda, E. Płuciennik, and A. K. Bednarek, "Proteins in cancer resistance," Advances in Hygiene and Experimental Medicine, vol. 68, pp. 616-632, 2014.

[37] M. Hassan, M. Kjos, I. F. Nes, D. B. Diep, and F. Lotfipour, "Natural antimicrobial peptides from bacteria: characteristics and potential applications to fight against antibiotic resistance," Journal of Applied Microbiology, vol. 113, no. 4, pp. 723-736, 2012.

[38] M. Wassef, H. E. Mahallawy, and M. M. Zafer, "Lab based surveillance of multidrug resistant Pseudomonas aeruginosa in Cairo university hospitals," Egyptian Journal of Microbiology, vol. 2, no. 1, pp. 47-51, 2015.

[39] H. Mohamed, M. Atef, S. Shibl, A. Zaki, and F. T. Abdulkader, "Antimicrobial resistance pattern and prevalence of metallo$\beta$-lactamases in Pseudomonas aeruginosa from Saudi Arabia," African Journal of Microbiology Research, vol. 5, no. 30, pp. 5528-5533, 2011.

[40] B. A. Mahmoud, A. W. Zahran, R. G. Hindawi, Z. A. Labib, and R. Galal, "Prevalence of multidrug-resistant Pseudomonas aeruginosa in patients with nosocomial infections at a university hospital in Egypt, with special reference to typing methods," Journal of Virology and Microbiology, vol. 2013, Article ID 290047, 13 pages, 2013.

[41] J. M. Rodríguez-Martínez, L. Poirel, and P. Nordmann, "Molecular epidemiology and mechanisms of carbapenem resistance in Pseudomonas aeruginosa," Antimicrobial Agents and Chemotherapy, vol. 53, no. 11, pp. 4783-4788, 2009.

[42] V. H. Tam, K.-T. Chang, K. Abdelraouf et al., "Prevalence, resistance mechanisms, and susceptibility of multidrug-resistant bloodstream isolates of Pseudomonas aeruginosa," Antimicrobial Agents and Chemotherapy, vol. 54, no. 3, pp. 1160-1164, 2010.

[43] S. Meenakumari, S. Verma, A. Absar, and A. Chaudhary, "Antimicrobial susceptibility pattern of clinical isolates of Pseudomonas aeruginosa in an Indian cardiac hospital," International Journal of Engineering Science and Technology, vol. 3, no. 9, pp. 7117-7124, 2011.

[44] I. A. Abdallah and M. E. Abdulla, "Antibiotic resistance in Pseudomonas aeruginosa isolated from various clinical specimens in Ibne Sina Hospital-Sirte-Libya," Bulletin of
Alexandria Faculty of Medicine, vol. 45, no. 3, pp. 771-775, 2009.

[45] G. T. Jombo, P. Jonah, and J. A. Ayeni, "Multiple resistant Pseudomonas aeruginosa in contemporary medical practice: findings from urinary isolates at a Nigerian University Teaching Hospital," Nigerian Journal of Physiological Sciences, vol. 23, no. 1-2, pp. 105-109, 2008.

[46] H. Y. Al Dawodeyah, N. Obeidat, L. F. Abu-Qatouseh, and A. A. Shehabi, "Antimicrobial resistance and putative virulence genes of Pseudomonas aeruginosa isolates from patients with respiratory tract infection," Germs, vol. 8, no. 1, pp. 31-40, 2018.

[47] D. A. Gray and M. Wenzel, "Multitarget approaches against multiresistant superbugs," ACS Infectious Diseases, vol. 6, no. 6, pp. 1346-1365, 2020.

[48] A. A. Alharbi, "Antibacterial activities of Syzygium aromaticum oil against local 679 clinical pathogenic bacteria," International Journal of International Studies in Sciences and 680 Engineering Technology, vol. 3, pp. 7-11, 2017.

[49] R. Sibanarayan and N. Rabindra, "Monitoring in vitro antibacterial efficacy of 26 Indian spices against multidrug resistant urinary tract infecting bacteria," Integrative Medicine Research, vol. 3, no. 3, pp. 133-141, 2014.

[50] K. S. Vanka, M. Aparna, S. Astha, D. Supriya, and J. O. William, "Synergistic effect of Aloe vera and Curcuma longa extracts in the inhibition of drug-resistant E. coli," Journal of Pure and Applied Microbiology, vol. 8, no. 6, pp. 4693-4699, 2014.

[51] M. A. Aziz, M. Adnan, H. Rahman, A. Allah, and A. Hashem, "Antibacterial activities of medicinal plants against multidrug resistant urinary tract pathogens," Pakistan Journal of Botany, vol. 49, no. 3, pp. 1185-1192, 2017.

[52] R. Khan, B. Islam, M. Akram et al., "Antimicrobial activity of five herbal extracts against multi drug resistant (MDR) strains of bacteria and fungus of clinical origin," Molecules, vol. 14, no. 2, pp. 586-597, 2009.

[53] Y. Leyton, J. Borquez, J. Darias, M. Cueto, A. R. Díaz-Marrero, and C. Riquelme, "Oleic acid produced by a marine Vibrio spp. acts as an anti-Vibrio parahaemolyticus agent," Marine Drugs, vol. 9, no. 10, pp. 2155-2163, 2011.

[54] K. E. S. Locock, T. D. Michl, N. Stevens et al., "Antimicrobial polymethacrylates synthesized as mimics of tryptophan-rich cationic peptides," ACS Macro Letters, vol. 3, no. 4, pp. 319-323, 2014.

[55] M.-A. Boucher, H. Côté, A. Pichette, L. Ripoll, and J. Legault, "Chemical composition and antibacterial activity of Tussilago farfara (L.) essential oil from Quebec, Canada," Natural Product Research, vol. 34, no. 4, pp. 545-548, 2020. 